\title{
Impact of home visits on the functional capacity of patients with venous ulcers
}

\author{
Repercussão da visita domiciliar na capacidade funcional de pacientes com úlceras venosas
}

Repercusión de la visita domiciliaria en la capacidad funcional de pacientes con úlceras venosas

\begin{abstract}
Fabiana Lopes Joaquim', Alessandra Conceição Leite Funchal Camachoo ${ }^{1,11}$, Rose Mary Costa Rosa Andrade Silva',III, Bruna Silva Leite', Raquel Santos de Queiroz', Cíntia Raquel da Costa de Assis'

' Universidade Federal Fluminense, Aurora de Afonso Costa Nursing School, Postgraduate Program in Healthcare Sciences. Niterói, Rio de Janeiro, Brazil.

"Universidade Federal Fluminense, Aurora de Afonso Costa Nursing School, Department of Nursing and Administration Basis. Niterói, Rio de Janeiro, Brazil.

II' Universidade Federal Fluminense, Aurora de Afonso Costa Nursing School,

Department of Medical and Surgical Nursing. Niterói, Rio de Janeiro, Brazil.

How to cite this article:

Joaquim FL, Camacho ACLF, Silva RMCRA, Leite BS, Queiroz RS, Assis CRC. Impact of home visits on the functional capacity of patients with venous ulcers. Rev. Bras. Enferm. [Internet]. 2017;70(2):287-93.

DOI: http://dx.doi.org/10.1590/0034-7167-2016-0291

Submission: 06-17-2016 Approval: 09-02-2016

ABSTRACT

Objective: to compare the impact of home visits, before and after instructions, on the functional capacity of adult and elderly patients with venous ulcers, by means of the KATZ-EIAVD Scale. Method: experimental, clinical, randomized, non-blind and controlled study, developed with 32 patients (case and control groups). The research settings were the Wound Care Clinic of the University Hospital Antonio Pedro, and the homes of patients assisted in this clinic. Data collection took place from February to June 2014, by means of a health unit evaluation tool, the KATZ-EIAVD Scale, and a script of instructions to be given to the research subjects that had received a home visit. Results: the studied population present excellent independence for activities of daily living, with no significant variation among them. Conclusion: the studied groups have functional capacity with similar progress.
\end{abstract}

Descriptors: Nursing Care; Varicose Ulcer; Home Visit; Adult; Aged.

\section{RESUMO}

Objetivo: comparar a repercussão da visita domiciliar, antes e após orientações, na capacidade funcional de pacientes adultos e idosos com úlceras venosas, por meio da Escala de KATZ-EIAVD. Método: estudo clínico experimental, randomizado, não cego e controlado, desenvolvido com 32 pacientes (grupos caso e controle). Os campos de investigação foram o Ambulatório de Reparo de Feridas do Hospital Universitário Antônio Pedro e os domicílios de pacientes atendidos no referido ambulatório. A coleta ocorreu de fevereiro a junho de 2014, por meio de instrumento de avaliação da unidade de saúde, da Escala de KATZEIAVD e de roteiro de orientações a serem prestadas aos sujeitos da pesquisa que receberam visita domiciliar. Resultados: as populações estudadas apresentam ótima independência nas atividades de vida diária, sem variação significativa entre si. Conclusão: os grupos estudados apresentam a capacidade funcional evoluindo de modo semelhante.

Descritores: Cuidados de Enfermagem; Úlcera Varicosa; Visita Domiciliar; Adulto; Idoso.

\section{RESUMEN}

Objetivo: comparar la repercusión de la visita domiciliaria, antes y después de indicaciones, en la capacidad funcional de pacientes adultos y ancianos con úlceras venosas, mediante Escala de KATZ-EIAVD. Método: estudio clínico experimental, randomizado, no ciego, controlado, desarrollado con 32 pacientes (grupos caso y control). Los campos de investigación fueron el Ambulatorio de Curación de Heridas del Hospital Antônio Pedro y los domicilios de pacientes allí atendidos. Datos recolectados de febrero a junio 
de 2014, mediante instrumento de evaluación de la unidad de salud, de la Escala de KATZ-EIAVD y de la rutina de indicaciones a brindarse a los sujetos de la investigación que recibieron visita domiciliaria. Resultados: las poblaciones estudiadas presentan óptima independencia en sus actividades de la vida diaria, sin cambios significativos entre sí. Conclusión: los grupos estudiados presentan capacidades funcionales evolucionando de manera semejante.

Descriptores: Atención de Enfermería; Úlcera Varicosa; Visita Domiciliaria; Adulto; Anciano.

\section{INTRODUCTION}

Functional capacity refers to an individual's conditions of living independently, and interacting with their environment ${ }^{(1)}$. Thus, functional capacity evaluation allows checking an individual's independence in carrying out basic and instrumental activities, which are represented by the following activities: taking a bath, getting dressed, carrying out personal hygiene, moving, eating, keeping continence, preparing meals, controlling finances, taking medicines, cleaning the house, shopping, using public transport, using the telephone, and walking a certain distance.

Because functional capacity declines with age, it becomes necessary to create strategies aimed at the promotion, treatment and rehabilitation of people's functional capacity and social integration ${ }^{(2)}$. Hence, and since chronic venous ulcers are evidenced as an epidemiological problem of high incidence and prevalence among adults and elderly people $\mathrm{e}^{(3-4)}$ that affects the lower limbs and impacts quality of life and productivity, it becomes necessary to evaluate the functional capacity of people suffering from it, who experience pain, edema, and consequently, locomotion difficulties.

In this context, home care is presented as care activities developed at home, by healthcare professionals, with the level of complexity of an outpatient service ${ }^{(5)}$. These care activities have complex performance, thus the professionals who develop them must have consistent technical training.

Home visits are seen as a chance to get further information about patients' life conditions, their family dynamics and life style, and are pointed as a factor of improvement in the quality of the care provided to patients, as well as a contributing factor to the finances of patients who suffer from chronic diseases ${ }^{(6)}$, because it allows better integration of the actions that occur in the home context and of those occurring in the health services.

Ulcerative lesions cause, in the patients and their family members, difficulties related to the need for adaptation to the clinical condition, leading to rethinking of values, comprehension of the disease, adherence to procedures, and coping with myths and stigma from society ${ }^{(7)}$. Thus, nurses should be attentive to patients, and develop educational support to assist them. When developing educational support to the patients, nurses aim to guide them to find an adaptive means to overcome their clinical condition, projecting effective recovery and, consequently, improving their quality of life $\mathrm{e}^{(7)}$. This educational support is crucial for the behaviors targeting recovery to be discussed and slowly adopted, so as to make treatment effective and satisfactory to patients' biopsychosocial conditions.

This is a relevant study because the educational support provided by means of healthcare guidance to these patients regarding the way care is given, along with the creation, adaptation, and transformation targeted at the emancipation of the cared subject ${ }^{(5)}$, allows to change the moment of care into an encounter between the caregiver and the cared subject, by means of a reflexive practice that contributes to care practice ${ }^{(8)}$.

According to the above, the objective of the present study is to compare the impact of home visits, before and after instructions, on the functional capacity of adults and elderly patients with venous ulcers, by means of the KATZ-EIAVD Scale.

\section{METHOD}

\section{Ethical aspects}

The development of this study complied with Resolution no. 466, of December 12, 2012, of the National Health Council/Ministry of Health that, by means of its legal competences, establishes guidelines and norms that regulate studies involving human subjects. The research was approved by the Human Research Ethics Committee of the University Hospital Antonio Pedro (HUAP).

\section{Study design, setting and period}

This is an experimental, clinical, randomized, non-blind and controlled study. It was developed in two different settings: the Wound Care Clinic of the University Hospital Antonio Pedro, and the homes of patients assisted in this clinic. Data collection occurred from February to June, 2014, as a result of demand for outpatient services.

\section{Population or sample: inclusion and exclusion criteria}

The study had 32 participants. The study inclusion criteria were: adult and elderly patients with venous ulcers in one or both lower limbs presenting cognitive conditions to follow the recommended instructions, during the study period, since the department also assists patients with cognitive deficit, and who agreed to voluntarily participate in the study. The exclusion criteria were: adult and elderly patients with arterial ulcers, diabetic foot, lack of compliance with the proposed care standards, and lack of continuous attendance to the appointments scheduled with the nursing staff.

After participant selection, a raffle was performed to define those who would integrate the case group and the control group, through Biostat 5.0 Software. The raffle was carried out by a statistician, to avoid bias of selection, with 16 people being allocated in each group.

\section{Study protocol}

For the case group, the protocol adopted was the performance of home visits to make dressings, followed by instructions 
directed to the treatment and prevention of venous ulcers wound cleaning, dressings, food and nutrients that are necessary to healing, elastic and non-elastic compression therapies, use of compressive stockings for the prevention of recurrences, and elevation of lower limbs to improve venous return. The control group received home visits for the performance of dressings, but with no further instructions besides those received in the outpatient service. Participants were reevaluated 15 days after the home visit.

For data collection, we chose to use the instrument of the health unit for evaluation of patients with venous ulcers, which was created based on patients' sociodemographic data and records regarding length of treatment and number of recurrences; the Katz Index of Independence in Activities of Daily Living (KATZ-EIAVD Scale); and a schedule developed for registering the instructions to be given to the research subjects who received home visits.

\section{Analysis of the results and statistics}

The analysis of the results involved descriptive statistics analysis and inferential analysis, with the first one being presented as a table, and the information collected expressed as for the frequency $(\mathrm{n})$ and percentage (\%) for categorical data, and based on mean, standard deviation, median, and minimum and maximum values, for numerical data.

Inferential analysis consisted of the following tests: $X^{2}$ test, or Fisher's exact test, Student's $t$ test, and Mann-Whitney test, to check eventual significant differences in the baseline sociodemographic variables, and those of the KATZ-EIAVD Scale, between the groups (case and control); McNemar Test, to analyze the evolution before and after the intervention in each group, being also applied for the individual questions; and Wilcoxon signed-rank test, applied to evaluate the scores of the respective scales.

Mann-Whitney test was also used to check the existence of significant differences in the delta scores of the scales composing the KATZEIAVD Scale, between the groups.

The criterion for determining the significance adopted in the study was the $5 \%$ level (a); a statistical test power of $80 \%(1-\beta)$, and expected increase in score in the group with a "relatively moderate" intervention, known as effect size $(\mathrm{ES} \approx 1)$.

\section{RESULTS}

Table 1 provides the sociodemographic and clinical descriptive analysis of the case and control groups through the frequency $(n)$, percentage $(\%)$, and corresponding descriptive level ( $p$ value) of the chi-square test $\left(X^{2}\right)$ or Fisher's exact test. The age was expressed by the mean \pm standard deviation (SD), and compared by Student's $t$ test for independent samples.

Tables 2 and 3 provide the frequency (n) and percentage $(\%)$ of the questions of the KATZ-EIAVD scale, before and after the intervention, for the case and control groups, respectively, and the corresponding descriptive level ( $p$ value) of the $\mathrm{McNe}$ mar test. The total score was expressed through the median (minimum - maximum) and analyzed through the Wilcoxon signed-rank test.

The data presented on Table 4 demonstrate that there is no significant difference in the delta of the KATZ scale score $(p$ $=0.073$ ), between the two groups, indicating that they evolve similarly.

Table 1 - Analysis of the sociodemographic and clinical variables according to the case and control groups, Niterói, Rio De Janeiro, Brazil, 2014

\begin{tabular}{|c|c|c|c|c|c|c|}
\hline \multirow{2}{*}{ Características } & \multirow{2}{*}{ Categorias } & \multicolumn{2}{|c|}{$\begin{array}{l}\text { Case group } \\
(\mathrm{n}=16)\end{array}$} & \multicolumn{2}{|c|}{$\begin{array}{c}\text { Control group } \\
(\mathrm{n}=16)\end{array}$} & \multirow{2}{*}{$\underset{\text { value }^{a}}{p}$} \\
\hline & & $\mathbf{n}$ & $\%$ & $\mathbf{n}$ & $\%$ & \\
\hline \multirow[t]{2}{*}{ Sex } & Female & 10 & 62.5 & 8 & 50.0 & 0.48 \\
\hline & Male & 6 & 37.5 & 8 & 50.0 & \\
\hline Age (years) $*$ & & \multicolumn{2}{|c|}{$60.1 \pm 9.7$} & \multicolumn{2}{|c|}{$66.9 \pm 11.6$} & 0.080 \\
\hline \multirow[t]{3}{*}{ Ethnic group } & White & 5 & 31.3 & 5 & 31.3 & 0.44 \\
\hline & Black & 9 & 56.3 & 6 & 37.5 & \\
\hline & Brown & 2 & 12.5 & 5 & 31.3 & \\
\hline \multirow[t]{4}{*}{ Level of education } & Functional illiterate & 1 & 6.3 & 1 & 6.3 & 0.99 \\
\hline & Primary education & 9 & 56.3 & 8 & 50.0 & \\
\hline & High school & 5 & 31.3 & 6 & 37.5 & \\
\hline & Undergraduate degree & 1 & 6.3 & 1 & 6.3 & \\
\hline \multirow[t]{4}{*}{ Marital status } & Single & 3 & 18.8 & 2 & 12.5 & 0.63 \\
\hline & Married & 6 & 37.5 & 9 & 56.3 & \\
\hline & Divorced & 3 & 18.8 & 1 & 6.3 & \\
\hline & Widowed & 4 & 25.0 & 4 & 25.0 & \\
\hline \multirow[t]{3}{*}{ City } & Niterói & 8 & 50.0 & 7 & 43.8 & 0.78 \\
\hline & São Gonçalo & 6 & 37.5 & 8 & 50.0 & \\
\hline & Itaboraí & 2 & 12.5 & 1 & 6.3 & \\
\hline \multirow[t]{3}{*}{ Source of income } & Retired & 11 & 68.8 & 16 & 100 & 0.043 \\
\hline & Pension & 3 & 18.8 & 0 & 0.0 & \\
\hline & Job & 2 & 12.5 & 0 & 0.0 & \\
\hline \multirow[t]{3}{*}{ Family income } & 1 to $2 \mathrm{MW}$ & 16 & 100 & 12 & 75.0 & 0.10 \\
\hline & 2 to $4 \mathrm{MW}$ & 0 & 0.0 & 3 & 18.8 & \\
\hline & $>4 \mathrm{MW}$ & 0 & 0.0 & 1 & 6.3 & \\
\hline \multirow[t]{3}{*}{ Length of treatment } & $6 \mathrm{~m}$ to 1 year & 4 & 25.0 & 6 & 37.5 & 0.85 \\
\hline & 1 to 5 years & 1 & 6.3 & 1 & 6.3 & \\
\hline & $>5$ years & 11 & 68.8 & 9 & 56.3 & \\
\hline \multirow[t]{3}{*}{ No. of recurrences } & Never & 5 & 31.3 & 8 & 50.0 & 0.45 \\
\hline & 1 to $4 x$ & 7 & 43.8 & 4 & 25.0 & \\
\hline & $5 x$ or + & 4 & 25.0 & 4 & 25.0 & \\
\hline
\end{tabular}

Note: ${ }^{a} \mathrm{X} 2$ test or Fisher's exact test; ${ }^{*}$ expressed by the mean $\pm S D$ and compared by Student's $t$ test for independent samples; $M W=$ minimum wage $(R \$ 724.00)$. 
Table 2 - KATZ-EIAVD Scale before and after the intervention of the case group, Niterói, Rio De Janeiro, Brazil, 2014

\begin{tabular}{|c|c|c|c|c|c|c|}
\hline \multirow{2}{*}{ KATZ domains } & \multirow{2}{*}{ Response } & \multicolumn{2}{|c|}{ Before } & \multicolumn{2}{|c|}{ After } & \multirow{2}{*}{$\underset{\text { value }^{a}}{p}$} \\
\hline & & $\mathbf{n}$ & $\%$ & $\mathbf{n}$ & $\%$ & \\
\hline \multirow{2}{*}{ Bath } & Poor & 0 & 0 & 0 & 0 & \multirow{2}{*}{ NP } \\
\hline & Good & 16 & 100 & 16 & 100 & \\
\hline \multirow{2}{*}{ Clothes } & Poor & 1 & 6.3 & 1 & 6.3 & \multirow{2}{*}{1} \\
\hline & Good & 15 & 93.8 & 15 & 93.8 & \\
\hline \multirow{2}{*}{ Hygiene } & Poor & 0 & 0 & 0 & 0 & \multirow{2}{*}{ NP } \\
\hline & Good & 16 & 100 & 16 & 100 & \\
\hline \multirow{2}{*}{ Transfer } & Poor & 3 & 18.8 & 2 & 12.5 & \multirow{2}{*}{1} \\
\hline & Good & 13 & 81.3 & 14 & 87.5 & \\
\hline \multirow{2}{*}{ Continence } & Poor & 6 & 37.5 & 4 & 25.0 & \multirow{2}{*}{0.50} \\
\hline & Good & 10 & 62.5 & 12 & 75.0 & \\
\hline \multirow{2}{*}{ Food } & Poor & 0 & 0 & 0 & 0 & \multirow{2}{*}{ NP } \\
\hline & Good & 16 & 100 & 16 & 100 & \\
\hline Total score of KATZ * & & \multicolumn{2}{|c|}{$5(4-6)$} & \multicolumn{2}{|c|}{$6(4-6)$} & 0.25 \\
\hline
\end{tabular}

Note: ${ }^{a}$ McNemar test; $N P=$ does not process the statistic test; ${ }^{*}$ expressed by the median (minimum - maximum) and compared by the Wilcoxon signed-rank test.

Table 3 - KATZ-EIAVD Scale before and after the intervention in the control group, Niterói, Rio de Janeiro, Brazil, 2014

\begin{tabular}{|c|c|c|c|c|c|c|}
\hline \multirow{2}{*}{ KATZ domains } & \multirow{2}{*}{ Response } & \multicolumn{2}{|c|}{ Before } & \multicolumn{2}{|c|}{ After } & \multirow{2}{*}{$\underset{\text { value }}{p}$} \\
\hline & & $\mathbf{n}$ & $\%$ & $\mathbf{n}$ & $\%$ & \\
\hline \multirow{2}{*}{ Bath } & Poor & 2 & 12.5 & 2 & 12.5 & \multirow{2}{*}{1} \\
\hline & Good & 14 & 87.5 & 14 & 87.5 & \\
\hline \multirow{2}{*}{ Clothes } & Poor & 1 & 6.2 & 1 & 6.2 & \multirow{2}{*}{1} \\
\hline & Good & 15 & 93.8 & 15 & 93.8 & \\
\hline \multirow{2}{*}{ Hygiene } & Poor & 2 & 12.5 & 2 & 12.5 & \multirow{2}{*}{1} \\
\hline & Good & 14 & 87.5 & 14 & 87.5 & \\
\hline \multirow{2}{*}{ Transfer } & Poor & 1 & 6.2 & 1 & 6.2 & \multirow{2}{*}{1} \\
\hline & Good & 15 & 93.8 & 15 & 93.8 & \\
\hline \multirow{2}{*}{ Continence } & Poor & 6 & 37.5 & 6 & 37.5 & \multirow{2}{*}{1} \\
\hline & Good & 10 & 62.5 & 10 & 62.5 & \\
\hline \multirow{2}{*}{ Food } & Poor & 0 & 0 & 0 & 0 & \multirow{2}{*}{ NP } \\
\hline & Good & 16 & 100 & 16 & 100 & \\
\hline Total score of KATZ * & & \multicolumn{2}{|c|}{$5.5(2-6)$} & \multicolumn{2}{|c|}{$5.5(2-6)$} & 1 \\
\hline
\end{tabular}

Note: ${ }^{a}$ McNemar test; $N P=$ does not process the statistical test; * express for the median (minimum - maximum) and compared by Wilcoxon signed-rank test.

Table 4 - Absolute delta of the KATZ scale scores, according to the group

\begin{tabular}{lccc}
\hline Scale & Case group & Control group & $\boldsymbol{p ~ v a l u e ~}^{\boldsymbol{a}}$ \\
\hline KATZ* $^{*}$ & $0(0-1)$ & $0(0-0)$ & 0.073 \\
\hline
\end{tabular}

Note: ${ }^{a}$ Mann-Whitney test; ${ }^{*}$ the deltas were expressed by the median (minimum - maximum).

\section{DISCUSSION}

The characterization of the sociodemographic variables of the case and control groups allowed to identify that $56.2 \%$ of the study participants were women, and $43.8 \%$ were men. The predominance of female subjects for the development of venous ulcers is evidenced in several studies that relate this predisposition to female hormones and to pregnancy ${ }^{(9-10)}$. The authors of the related studies point that hormonal disorders lead to a predisposition for chronic venous insufficiency and, consequently, to the formation of venous ulcers.

The values related to age show that the mean was of 63.5 years, with $46.9 \%$ being in the age group of 40 to 59 years, and $53.1 \%$, in the age group of 60 to 79 years. The incidence of chronic venous insufficiency shows high indices as of the third decade of life, affecting individuals in full maturity, and inserted in the labor market ${ }^{(11)}$. This is observed in our study, since $46.9 \%$ of the participants were adults (from 40 to 59 years), and generates concern because ulcerative lesions are difficult to heal, leading people affected by them to quit work or to retire.

Quitting from work and retiring cause an unbalance in the economically active population, leading to damages for the labor market and quality of life $^{(12)}$, because individuals lose their social identity. Although the results of the research demonstrate that we should be attentive to the high index of adults affected by chronic venous ulcers, the study in question evidenced the predominance of elderly subjects $(53.1 \%)$, which corroborates the findings of other studies ${ }^{(10,13)}$.

Regarding the participants' ethnic group, we found a predominance $(46.9 \%)$ of participants who are self-declared black, followed by $31.2 \%$ who self-declare themselves as white, and $21.9 \%$ who self-declare themselves as brown. The black and brown ethnicities are evidenced as predominant in national and international studies ${ }^{(14-16)}$.

The occurrence of chronic venous insufficiency and ulcerations is related to the presence of the etiological factor that is the venous insufficiency triggered by venous hypertension. Thus, venous hypertension can occur in the population that presents one or more risk factors, such as: valvular incompetence, which hinders the retrograde flow; calf muscle pump impairment, resulting in incomplete venous emptying; deep venous thrombosis; multiple pregnancies, edema, obesity, ascites, congenital anomaly, severe traumas or tumors in the lower limbs; congestive heart failure, and sedentary life style or labor ${ }^{(17)}$.

Regarding education level, a low level of education was evidenced in the research participants, with $6.3 \%$ of functional illiterates, $53.1 \%$ having primary education, $34.3 \%$ having high school, and 
$6.3 \%$ having graduated. These findings do not differ from other studies carried out in an outpatient service $\mathrm{e}^{(3,13-14,18-19)}$.

It is important to be attentive to the level of education of the subject who is assisted, because the low level of education can interfere directly with the understanding of the pathology, assimilation of the care process, applicability of the interventions related to the treatment of lesions, and change of behavior and attitude at home ${ }^{(20)}$.

Regarding patients' marital status, there was a predominance of married people, corroborating the profile of participants of other studies ${ }^{(13-14,18)}$. Most people with venous ulcers do not receive family support during the treatment, and suffer discrimination from the family ${ }^{(7)}$; thus, the predominance of married people in our study evidences the acceptance and support of the friends facing the pathology, because the changes caused by the lesion, such as change in life style, and isolation due to pain, difficulty of locomotion, and physical appearance, can generate family crises, abandonment of the partner, and consequently, depression of the subject with venous ulcer.

Regarding the city where the participants of the research live, the city of Niterói predominated (46.9\%), followed by São Gonçalo $(43.8 \%)$, and Itaboraí $(9.3 \%)$. Because the Wound Care Clinic of the University Hospital Antonio Pedro was the place where these participants were monitored, we should be concerned about these subjects' functional capacity, because they need to move from their houses, for hours, to seek care.

A high number of patients from other cities undergo nursing consultations at the Wound Care Clinic of the HUAP because the department is considered a reference in the treatment of chronic lesions in Niterói/RJ; service is provided by a multidisciplinary team; and the city of origin of these patients does not have a reference outpatient service for treating this type of lesion ${ }^{(3)}$.

The study participants' source of income is an issue that generates concern. As previously described, chronic venous ulcers affect individuals in full maturity and, in many cases, those who are inserted in the labor market but, as the ulcerative lesions are difficult to heal, many patients have to quit work or even retire.

The retirement issue is evidenced in this study, where $84.4 \%$ of the participants are retired, $9.4 \%$ are pensioners and only $6.2 \%$ work. The fact that chronic venous ulcers patients are, in their great majority, pensioners or do not to have an occupational activity, is also evidenced in other studies ${ }^{(13-14,18)}$. In view of what was mentioned regarding the source of income of the research participants, we observed that this is directly linked to the family income, that is, with most of them being retired, their monthly income is of a minimum wage.

When questioned about their family income, $87.5 \%$ of the participants stated that they had an income of 1 to 2 minimum wages, $9.4 \%$ of 2 to 4 minimum wages, and $3.1 \%$ said that their family income was of more than 4 monthly minimum wages. When tracing the sociodemographic profile of its participants, other studies ${ }^{(3,13-14,18)}$ also evidenced a low purchasing power of the population assisted in public outpatient services. This is worrisome, because the financial data reflect directly in care, since a low purchasing power can lead patients to choose to pay their monthly bills rather than carrying out the lesion care (going to consultations, adhering to treatment with the coverage proposed for the lesion).
Regarding the characterization of the clinical variables length of treatment and number of recurrences, these were issues that stood out, corroborating the statement that chronicity, and the recurrences of the injuries make patients live with this pathology for years ${ }^{(12)}$.

Research data evidenced that $62.5 \%$ of the participants had been on treatment for more than 5 years, having evidenced that the lesion treatment was difficult and long(21). Regarding the number of recurrences, $40.6 \%$ of the participants had never had the lesion healed, $34.4 \%$ presented 1 to 4 recurrences, and $25 \%$ of the participants had 5 or more recurrences within the period of treatment.

Cases of patients with several recurrences of venous ulcers are due to the lack of after-healing follow up by angiologists, no performance of surgeries, among others factors, such as the absence of contribution from patients regarding preventive measures ${ }^{(22)}$.

The functional capacity discussed, in this study, by means of the effect of instructions provided during home visits to patients with venous ulcers, used the KATZ-EIAVD Scale. The percentages obtained, when evaluating the participants before and after the intervention, demonstrate that the studied subjects presented excellent independence in basic activities of daily living.

The results of the case group demonstrated that, in the domain Bath, $100 \%$ of the participants presented good response before and after intervention, whereas in the control group these percentages were $87.5 \%$ before and after the period determined to reevaluate the intervention (15 days). In the domain Clothes, the case group presented, as a percentage of positive response, $93.8 \%$ before and after the intervention. The control group demonstrated, in this domain, $93.8 \%$ for the same response before and after the period of intervention.

In the domain hygiene, $100 \%$ of the participants of the case group showed good response and kept it, whereas in the control group, $87.5 \%$ had good response before and after the intervention period. Regarding transfer, $81.3 \%$ of the case group members had good response before the intervention and, after the instructions, started to present $87.5 \%$ of positive response, which demonstrates a $6.2 \%$ improvement. In the control group, this percentage was $93.8 \%$, remaining unchanged throughout the research.

Regarding continence, $62.5 \%$ of the case group members had good response before the intervention, and after the intervention this percentage was $75.0 \%$, demonstrating a $12.5 \%$ benefit in this issue after instructions. In the control group, the evaluation of this domain demonstrated that $62.5 \%$ of the members had a good response, with the same after-intervention period percentage.

In the domain Feeding, the case group and the control group had a good response and, in relation to the percentage, $100 \%$ before and after intervention.

The results analyzed above regarding the KATZ-EIAVD Scale demonstrated that the studied population presented excellent independence in activities of daily living, and demonstrated that the groups did not present significant variations between them. The KATZ Scale has also evidenced good percentile responses in other studies ${ }^{(14,23)}$, which demonstrates good independence of the subjects studied.

When we characterize the functional state of individuals, we should base their real state at the time of the evaluation, and not on the ability to carry out the task proposed without 
the aid of third parties ${ }^{(24)}$. Thus, being independent means being capable to perform the functions with no supervision.

Thus, although no significant changes were seen through the KATZ-EIAVD Scale, in the studied groups, before and after intervention, we evidence that the tool used was substantial for the evaluation of the research participants at home, demonstrating good functionality, and solving the doubts that can appear during the application of the scale $\mathrm{e}^{(24)}$, since the identification of the functional state is carried out by the researcher, rather than described by the participant.

\section{Study limitations}

The study presented, as limitation for its accomplishment, the absence of receptivity on the part of some participants, since many were distrustful for not inhabiting in safe places, which could put the professional safety at risk when visiting them. Another limitation regards the restricted number of articles in national and international databases that came to contribute for the discussion of the objective proposed, which highlights the importance to develop further studies related to the functional capacity of subjects with venous ulcers, providing an increase in the collection for researchers, professionals and students in the health area, since the related pathology presents high incidence and population prevalence.

Contributions for the fields of nursing, health or public policy

The main contribution of this study for the field of the scientific research on venous ulcers, and for nurses, was to investigate the impact of health instructions destined to the treatment and prevention of venous ulcers on functional capacity, as well as the functionality of the instrument for the evaluation of functional capacity, in what regards independence in activities of daily living. These findings are relevant, since the reduction or absence of this capacity can compromise the execution of daily, work and leisure activities, influencing significantly quality of life.

Regarding the advances for the area of knowledge, these involve the production and improvement of nursing care based on the prevention of worsening due to venous ulcers, by means of the development and adoption of new intervention techniques in nursing and health care. These actions aim at the recovery and rehabilitation of patients and the family involved in the care process.

\section{CONCLUSION}

This study enabled the comparison of the impact of home visits, before and after instructions, on the functional capacity of adult and elderly patients with venous ulcers, by means of the KATZ-EIAVD Scale.

The data collected in the groups during the research evidenced the need for better percentages within the domains, but when a comparative analysis before and after the intervention was performed, we noticed that, although the case group shows percentage improvements in the domains Transfer and Continence throughout the study, these alterations were not significant. Therefore, the comparison of the clinical characterization of the participants of the case group, before and after the intervention, through the KATZ-EIAVD scale, indicates that there is no significant variation, around $5 \%$ in the domains and total score of the group that presents a median of 5 before the intervention and 6 after the intervention.

The comparison of the clinical characterization performed in the control group also indicates that there is no significant variation in the questions and on the total score of the scale, which had a median of 5.5 before intervention, and 5.5 after the intervention, with this group being in steady clinical conditions.

The development of this study allowed to evidence that the KATZ-EIAVD Scale used to evaluate the level of independence of the subjects in activities of daily living, through six domains that refer to self-care activities, did not express significant changes in their functional capacity after the intervention of instructions, mainly in the members of the case group. This question can be verified by means of the statistical analysis of the collected data that demonstrates the absence of significant difference in the score delta of the scale ( $p=0.073$ ), between the case and control groups, indicating similar evolution between the groups.

When evidencing the need for improvement within the domains approached in the scale, we highlight the need for the development of studies and care strategies that value the improvement of the functional capacity of patients with venous ulcers.

\section{FUNDING}

This study received financial support from the Rio de Janeiro State Research Foundation (FAPERJ).

\section{REFERENCES}

1. Camacho ACLF, Santos RC, Joaquim FL, Louredo DS, Morais IM, Silva EA. Comparative study about the functional capacity of adult and elderly patients with venous ulcers. R Pesq: Cuid Fundamental [Internet]. 2015 [cited 2016 Apr 21];7(1):1954-66. Available from: http://www.seer.unirio.br/index.php/cuidadofundamental/article/viewFile/3505/pdf_1435

2. Torres GV, Reis LA, Fernandes MH, Alves GS. Avaliação da capacidade de realização das atividades cotidianas em idosos residentes em domicílio. Rev Baiana Saúde Pública [Internet]. 2009 [cited 2016 Apr 21];33(3):466-75. Available from: http://inseer.ibict.br/rbsp/index. php/rbsp/article/viewFile/227/pdf_42

3. Oliveira BGRB, Nogueira GA, Carvalho MR, Abreu AM. The characterization of patients with venous ulcer followed at the Outpatient Wound Repair Clinic. Rev Eletr Enf [Internet]. 2012 [cited 2016 Apr 22];14(1):156-63. Available from: http://www.fen.ufg.br/revista/v14/ n1/pdf/v14n1a18.pdf

4. Costa LM, Higino WJF, Leal FJ, Couto RC. Clinical and socio-demographic profile of patients with venous disease treated in health centers of Maceió (AL), Brazil. J Vasc Bras [Internet]. 2012 [cited 2016 Apr 22];11(2):108-13. Available from: http://www. 
scielo.br/pdf/jvb/v11n2/v11n2a07.pdf

5. Gallassi CV, Ramos DFH, Kinjo JY, Souto BGA. Home care in primary health care: na operational synthesis. ABCS Health Sci [Internet]. 2014 [cited 2016 Apr 22];39(3):177-85. Available from: http://www.portalnepas.org.br/abcshs/article/download/653/652.

6. Theile G, Kruschinski C, Buck M, Müller CA, Hummers-Pradie E. Home visits - central to primary care, tradition or an obligation? A qualitative study. BMC Family Practice [Internet]. 2011 [cited 2016 Apr 23];12(24):1:11. Available from: http://www.biomedcentral.com/content/ pdf/1471-2296-12-24.pdf

7. Costa IKF, Nóbrega WG, Costa IKF, Torres GV, Lira ALBC, Tourinho FSV, et al. People with venous ulcers: a study of the psychosocial aspects of the adaptive model of Roy. Rev Gaúcha Enferm (Online) [Internet]. 2011. [cited 2016 Apr 23];32(3):561-68. Available from: http://www.scielo.br/pdf/rgenf/v32n3/18.pdf

8. Waldow VR. Caring moment: moment of reflection in action. Rev Bras Enferm [Internet]. 2009 [cited 2016 Apr 24];62(1):140-5. Available from: http://www.reben.abennacional.org.br/detalhes/1024/momento-de-cuidar-momento-de-reflexao-na-acao

9. Macedo EB, Torres GV, Oliveira AA, Medeiros RS, Silva DN, Souza AG. Cost-effectiveness of compression therapy in people with venous ulcers. Rev Enferm UFPE on line [Internet]. 2013 [cited 2016 Apr 24];7(esp):6101-7. Available from: http://www.revista. ufpe.br/revistaenfermagem/index.php/revista/article/view/4580/pdf_3721

10. Fradique C, Pupo A, Quaresma L, Palma-Rosa A, Fernandes M, Silva G, et al. Úlcera flebostática-estudo prospectivo de 202 doentes. Acta Med Port [Internet]. 2011 [cited 2016 Apr 24];24(1):71-80. Available from: http://www.actamedicaportuguesa.com/ revista/index.php/amp/article/view/341/111

11. Abreu AM, Oliveira BGR. A study of the Unna Boot compared with the elastic bandage in venous ulcers: a randomized clinical trial. Rev Latino-Am Enfermagem[Internet]. 2015 [cited 2016 Apr 25];23(4):571-7. Available from: http://www.scielo.br/pdf/rlae/v23n4/0104-1169rlae-23-04-00571.pdf

12. Rodrigues ALS, Oliveira BGR, Futuro DO, Secoli SR. Effectiveness of papain gel in venous ulcer treatment: randomized clinical trial. Rev Latino-Am Enfermagem (Online) [Internet]. 2015 [cited 2016 Apr 25];23(3):458-65. Available from: http://www.scielo. br/pdf/rlae/v23n3/0104-1169-rlae-0381-2576.pdf

13. Malaquias SG, Bachion MM, Sant'Ana SMSC, Dallarmi CCB, Lino JRS, Ferreira PS. People with vascular ulcers in outpatient nursing care: a study of sociodemographic and clinical variables. Rev Esc Enferm USP [Internet]. 2012 [cited 2016 Apr 26];46(2):302-10. Available from: http://www.scielo.br/pdf/reeusp/v46n2/a06v46n2.pdf Portuguese

14. Camacho ACLF, Santos RC, Joaquim FL, Abreu CPM. Evaluation of functional capacity in care of tissue injuries of adults and elderly patients. Rev Pesq: Cuid Fundamental[Internet]. 2014 [cited 2016 Apr 26];6 (1):17-26. Available from: http://www.seer. unirio.br/index.php/cuidadofundamental/article/view/2651/pdf 1038

15. Souza EM, Yoshida WB, Melo VA, Aragão JA, Oliveira LA. Ulcer Due to Chronic Venous Disease: a sociodemographic study in Northeastern Brazil. Ann Vasc Surg [Internet]. 2013 [cited 2016 Apr 27];27(5):571-76. Available from: http://www.annalsofvascularsurgery.com/ article/S0890-5096\%2813\%2900046-0/pdf

16. Thomas DR. Managing venous stasis disease and ulcer. Clin Geriatr Med [Internet]. 2013 [cited 2016 Apr 27];29(2):415-24. Available from: http://www.sciencedirect.com/science/article/pii/S0749069013000074

17. Medeiros ABA, Frazão CMFQ, Tinôco JDS, Paiva MGMN, Lopes MVO, Lira ALBC. Venous ulcer: risk factors and the Nursing Outcomes Classification. Invest Educ Enferm [Internet]. 2014 [cited 2016 Apr 28];32(2):252-9. Available from: http://www.scielo.org.co/ $\mathrm{pdf} / \mathrm{iee} / \mathrm{v} 32 \mathrm{n} 2 / \mathrm{v} 32 \mathrm{n} 2 \mathrm{a} 08 . \mathrm{pdf}$

18. Angélico RCP, Oliveira AKA, Silva DDN, Vasconcelos QLDAQ, Costa IKF, Torres GV. Socio-demographic profile, clinical and health of people with venous ulcers treated at a university hospital. Rev Enferm UFPE[Internet]. 2012 [cited 2016 Apr 28];6(1):62-8. Available from: http://www.revista.ufpe.br/revistaenfermagem/index.php/revista/article/download/2100/2698

19. Nóbrega WG, Melo GSM, Costa IKF, Dantas DV, Macêdo EAB, Torres GV, et al. Changes in patients' quality of life with venous ulcers treated at the outpatient clinico f a university hospital. Rev Enferm UFPE [Internet]. 2011 [cited 2016 Apr 28];5(2)220-27. Available from: http://www.revista.ufpe.br/revistaenfermagem/index.php/revista/article/download/1478/1751

20. Azoubel R, Torres GV, Silva LWS, Gomes FV, Reis LA. Effects of the decongestive physiotherapy in the healing of venous ulcers. Rev Esc Enferm USP [Internet]. 2010 [cited 2016 Apr 28];44(4):1080-6. Available from: http://www.scielo.br/pdf/reeusp/v44n4/33.pdf

21. Belczaki SQ, Gornati VC, Aun R, Sincos IR, Fragoso H. Treatment of varicose ulcer of the lower limbs by surgery and Unna boot: savings for the Brazilian healthcare system. Einstein [Internet]. 2011 [cited 2016 Apr 29];9(3):377-85. Available from: http://www.scielo.br/pdf/ eins/v9n3/1679-4508-eins-9-3-0377.pdf

22. Reis DB, Peres GA, Zuffi FB, Ferreira LA, Poggetto MTD. Care for people with venous ulcers: the perception of nurses in the family health strategy. Rev Min Enferm [Internet]. 2013[cited 2016 Apr 29];17(1):108-12. Available from: http://www.reme.org.br/artigo/detalhes/582 Portuguese

23. Pereira GN, Bastos GAN, Del Duca GF, Bós AJG. Socioeconomic and demographic indicators associated with functional disability in the elderly. Cad Saúde Pública [Internet]. 2012 [cited 2016 Apr 29];28 (1):2035-42. Available from: http://www.scielo.br/pdf/ Csp/v28n11/03.pdf

24. Lino VTS, Pereira SRM, Camacho LAB, Ribeiro FST, Buksman S. Cross-cultural adaptation of the Independence in Activities of Daily Living Index (Katz Index). Cad Saúde Pública [Internet]. 2008 [cited 2016 Apr 30];24(1):103-12. Available from: http:// www.scielo.br/pdf/csp/v24n1/09.pdf 